\title{
Enhancement of public fiscal competence as educational process tendency in Russia
}

\author{
Elena N. Nikonova ${ }^{1 \mathrm{a}}$, Chulpan M. Shavaleeva ${ }^{1}$ \\ ${ }^{1}$ Kazan Federal University, 4, Butlerov st., Kazan, 420012, Russia
}

\begin{abstract}
According to the Russian Constitution "everyone has the right to seek, receive, transmit, produce and disseminate information freely by any legal means." In turn, the budget legislation of Russia has declared the openness of budget information. In recent years, the Russian Federation sees a lot of practical effort to implement the budget transparency principle; the results of this process are appreciated by the international community. But the problem is that budget information transparency (openness) does not presuppose that it is understood by all country citizens. Ongoing Russian government openness projects create opportunities to consider the views of the public in the course of draft budgets preparation; but for the general public to be able to formulate and express these opinions properly, they need to possess at least some basic knowledge regarding the fundamentals of the country's budget system. Russian education system is to play the most important role in addressing these issues. The article deals with the prospects of Russian educational process development to increase the level of citizens' budget literacy.
\end{abstract}

Keywords: Financial literacy; budget literacy, budget for public.

\section{Introduction}

One of the aims of the State program of the Russian Federation "Development of Education" for 2013-2020 is to ensure the high quality of Russian education in accordance with the changing needs of the population and the future tasks of the Russian economy and society. One of these long-term tasks is to enlarge the civil society participation in the processes of development and examination of the decisions taken by the public sector authorities. Ultimately, it concerns the broaden options for practical implementation of the Russian citizens constitutional right to participate in managing state affairs both directly and through their representatives (right under Article 32 of the Russian Federation Constitution). The government and civil society should be engaged in the budget process,

\footnotetext{
${ }^{a}$ Corresponding author: elnik-fin@mail.ru
} 
but the problem is that the majority of citizens' financial and budgetary ignorance is an obstacle to the revitalization of this interaction. For public opinion, suggestions and recommendations to be considered by the authorities in the relevant decision-making, it is necessary for them to be financially well-articulated and justified. This is the only way to ensure effective interaction of the government and society, the quality and balance of the decisions relating to public finance management. That is why the revitalization of the process of civil society involving in the government decision-making regarding state and municipal finances management will largely depend on the level of budget literacy. All these determine the relevance of the research in this area.

In recent years, financial literacy and practical measures for its enhancement has been the focus of authorities' attention. In 2011, the Russian Federation Ministry of Finance with the support of the World Bank launched the project "Facilitation of the financial literacy and financial education enhancement in the Russian Federation" (hereinafter - the project), the implementation of which should be completed by June 30, 2016. The purpose of the project is the improvement of Russian citizens' financial literacy (especially in schools and universities, as well as among adults with low and middle income), promoting reasonable financial behavior, informed decisions and responsible attitude to personal finance, improving the efficiency of financial services consumer rights protection. Thus, the project aimed at improving financial literacy, is intended to lay the foundations for the financial well-being of the citizens in the long run. At the same time, budget literacy involves awareness of citizens about the functioning of the country budgetary system. The aim of this work is to study substantive aspects of the "financial literacy" and "budget literacy" concepts, to investigate the Russian experience of facilitating financial literacy improvement, to define the educational process development prospects in Russia in the direction of increasing the level of public budget literacy.

\section{Theory}

In international practice, financial literacy is defined as the ability of individuals to manage their finances and take effective short-term and long-term financial decisions closely related to financial education, [16]. The study in the framework of the Program for International Student Assessment (PISA), run by OECD since 2000, uses the following working definition of financial literacy: "Financial literacy is the knowledge and understanding of financial concepts and financial risks, as well as the skills, motivation and confidence needed to make effective decisions in a variety of financial situations that contribute to improving the financial well-being of individuals and society, as well as opportunities to participate in economic life" (Financial literacy of Russian students).

It should be noted that in recent years the issue of financial education, financial literacy is actively studied and debated in the Russian and international research community. Among those who deeply investigate the issue are [1, 6, 8, 10, and 15]. The authors in their study highlight the need to separate the concepts of "financial literacy" and "budget literacy". Under budget literacy we mean citizens' knowledge about the fundamentals of country budget system organization and functioning, allowing them to participate in the preparation and examination of decisions taken by the authorities in the public finances management.

Financial literacy for an individual, as seen in Figure 1, is a prerequisite of effective management of one's personal finances, this management is aimed at improving the financial health of an individual.

Budget literacy, as shown in Figure 2, is regarded by the authors as a prerequisite to involve citizens in government decision-making regarding the public finances management. An important condition for the citizens' participation in the state (municipal) finances 
management is to ensure fiscal transparency. The 2007 report prepared by the International Monetary Fund, "Guidelines for providing fiscal transparency" interprets the concept of "fiscal transparency" as follows: "Openness to the general public in regard to the structure and functions of government, fiscal policy objectives, public sector accounts, and projections. It provides easy access to reliable, comprehensive, timely, understandable and comparable information among countries on the activities of government so that the electorate and financial markets can accurately assess the financial position of the government and the true costs and benefits associated with the activities of the government including its current and future economic and social consequences" (IMF, Guidelines for financial transparency, 2007). The paper states that the defining characteristic of fiscal transparency is the provision of public information to the society.

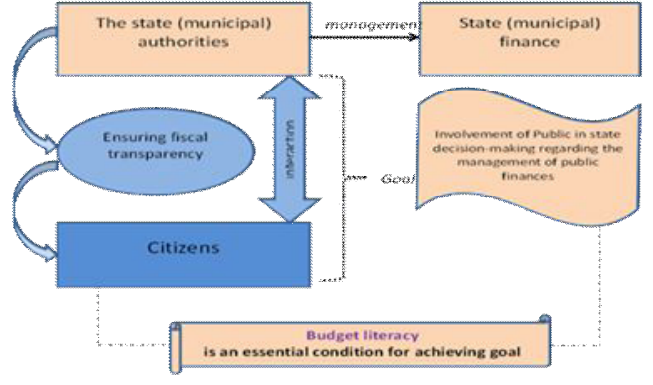

Fig. 1 The role of budget literacy in the public finances management

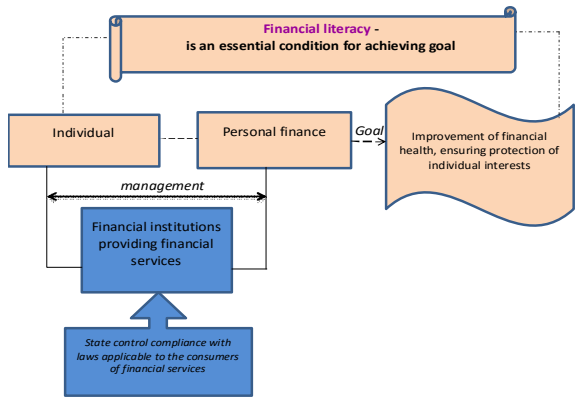

Fig. 2 The role of financial literacy in the personal finances management

\section{Results and Discussion}

In the framework of the project "Facilitation of the financial literacy and financial education enhancement in the Russian Federation" a variety of events takes place, including:

- A week of financial literacy for children and youth.

- All-Russian week of savings.

- Inter-regional seminars aimed at exchanging experience in the implementation of regional programs to improve financial literacy, the organization and conduct of information campaigns under the project at the federal and regional levels.

- Inter-regional conference on the implementation of educational programs in the field of financial literacy, financial literacy of young people, protection of financial services consumers' rights.

- All-Russian competition for the mass media in the financial education of the population.

- All-Russian competition for teachers to develop materials for financial literacy to be included in school curriculum.

- Independent monitoring of consumer protection in financial services.

The project has created more than 30 innovative teaching aids for additional education in schools, orphanages, secondary vocational education establishments.

It is worth noting that the project includes a lot of measures to improve young people financial literacy. The reason is quite obvious: not only the future personal well-being, but also sustainable socio-economic development of the country as a whole will depend on the financial culture of youth. In addition, according to the Rector of the Financial University under the Government of the Russian Federation Eskindarov M. A., "the implementation of 
the available educational initiatives for young people, initiated by the Russian Ministry of Finance, will allow to build a culture of financial conduct progressively and to raise the level of financial literacy not only among the students and pupils, but also among their parents. Undoubtedly, it will expand the participants groups of educational events, and will contribute to the growth of Russian citizens' well-being "(The first week of financial literacy for children and youth is over, 2015).

Exploring the issue of young people financial literacy, it should be noted that in 2012 in the framework of the Program for International Student Assessment (PISA), run by OECD, the first study of 15-year old students financial literacy have been implemented, where about 29 thousand students from 18 countries took part, including the Russian Federation. In accordance with international scale of the financial literacy $83.3 \%$ of Russian 15 -yearolds reached the threshold level (level 2) or exceeded it, with the highest level (Level 5) shown only by $4.3 \%$ of Russian students (the national average for OECD countries is $9.7 \%$, for Shanghai - 42.6\%); $16.7 \%$ of Russian students have not reached the financial literacy threshold level (average for the OECD countries - 15.3\%, for Shanghai - 5.1\%) (Financial literacy of Russian students, PISA, 2012). PISA study is conducted in a three-year cycle, the next phase of the research will be conducted in 2015 and Russia will participate in it. The results, which Russian participants must demonstrate, should highlight the changes in the level of financial literacy taken place since 2012 due to the measures implemented within the framework of the project "Facilitation of the financial literacy and financial education enhancement in the Russian Federation".

One of the project focuses is the implementation of regional programs to improve financial literacy. The number of regions where the project is being implemented, include: Volgograd region, Kaliningrad region, Tatarstan, Altai Territory, the Krasnodar Territory, Stavropol Territory, Arkhangelsk region, Saratov region, Tomsk region, Moscow. The main task of these regions is to develop and implement a package of measures to widespread financial literacy for all project target groups. As a result, the regions should form personnel, technology, infrastructure and information potential to effectively implement the task of population financial literacy improvement, and will lay the conditions for its future sustainability and replication of results in other regions of Russia after the end of the project.

Currently the joint project of the Russian Ministry of Finance and the World Bank is not the only initiative aimed at financial literacy increase. The Central Bank of the Russian Federation is also an active participant in this process. Thus, one of the largest projects of the Expert Council on Financial Literacy with the Central Bank of Russia is the project "A week of financial literacy in the Russia regions ", which has been implemented in 50 cities of Russia in 2010 - 2014 (Project "Week of financial literacy in Russian Regions"). The content of the programs in the city include: a conference for the economically active population (businessmen and investors); meetings with the management and staff of large enterprises; workshops for students of higher educational institutions; business games and training for elementary school, middle and high school pupils.

Thus, currently financial literacy of Russian citizens is provided primarily through the implementation of educational activities for young people. A major role in this process is played by higher education institutions, which increasingly open special centers (schools) of Financial Literacy. In November 2014 the National Agency for Financial Studies conducted initiative Russian opinion poll "Financial Literacy: "Who and what to teach?", where 1,600 people were interviewed at 140 settlements in 42 regions of Russia. Table 1 presents some of this survey results.

The survey results indicate that most Russians entrust the issue of increasing the financial literacy to the state and the universities, rather than non-governmental organizations, or financial advisors. 
As for measures aimed at improving budget literacy, most of them are measures to improve the transparency and openness of information about the state (municipal) finances management. Thus, one of the major projects in Russia within the framework of "Open Government" is a project "Budget for public" for clear and accessible presentation of the budget document. It should be noted that the main purpose of the "Open Government" functioning is the involvement of citizens and stakeholders in management decisions, to ensure their participation in an open examination of socially important legal acts drafts.

Table 1. Answers to the question "Today, many organizations related to financial markets are ready improve population financial literacy. Who would you like to see as a teacher in the program of financial literacy?

\begin{tabular}{lc}
\multicolumn{1}{c}{ Types of responses } & \% respondents \\
\hline Governmental organizations regulating these markets & 37 \\
Higher educational establishments with finance and economics profile & 27 \\
Pension funds and / or insurance companies & 23 \\
Independent financial consultants & 23 \\
Mass media (journalists and TV presenters) & 17 \\
Commercial bank & 14 \\
Mutual funds (Asset management companies) & 9 \\
Other people & 2 \\
Difficult to answer & 21 \\
\hline
\end{tabular}

*The sum of responses exceeds $100 \%$ because the question provided for the possibility of multiple choice.

"The budget for public" in Russia was first announced in the Russian President Budget Message on budget policy for 2014-2016, which, inter alia, stated that "since 2013 all government levels should regularly publish (or place in the Internet) a leaflet "The budget for public". This will allow to inform the population of the respective budgets, planned and achieved results of budgetary funds use in an accessible way. Information published in open sources will enable citizens to get an idea of the scope of budget spending and to draw conclusions about the effectiveness of spending and targeted use of resources" (Russian president budget message on budget policy 2014-2016). In August 2013 the "Guidelines for the budget presentation of the Russian Federation and local budgets and performance reports in the form accessible to the citizens" were approved. At the end of 2013 the first version of the "Budget for the public" at the federal level has been published. At the regional level, in 2013, 46 territorial entities of the Russian Federation presented regional budgets for public, in 2014 their number reached 77. Thus, in 2013 the practice of publishing the federal budget and budgets of Russian Federation territorial entities in the format of the "budget for public" becomes an annual event.

The measures implemented in the Russian Federation in recent years, indicate that governments at all levels attach great importance to the improvement of the situation with fiscal transparency. This has been appreciated by the international community as well. So, in early 2013, the International Budget Partnership published an Open Budget Survey of 100 countries for 2012. The Russian Federation is among ten leading countries which has increased its budget transparency index from 47 to 74 points according to the international ranking of the Open Budget in 2012. Such progress in the ranking is the evidence of the simplification of citizens' access to information relating to the budget process, empowering citizens to participate in the discussion of budgetary issues.

The International Monetary Fund has estimated the Russian fiscal transparency. At the request of the Russian Federation Ministry of Finance the mission of the IMF Fiscal Affairs Department and the Statistics Department conducted an assessment of budget reporting, budget forecasting and budgeting, as well as practice of budgetary risks management in Russia based on the standards set out in the revised IMF Draft Code of fiscal transparency from 15 to 30 October 2013. The results of the mission are reflected in the report "Russian Federation: Assessment of transparency in the fiscal area." In one section of the report titled "Executive Summary," the mission, among others, presents the following conclusions: most 
aspects of fiscal reporting and budgeting in Russia follow the best practices identified in the Draft Code of transparency in the fiscal area from July 2013, and the disclosure and management of fiscal risks have been significantly improved in recent years.

By 2018, the Russian Federation is planning to enter the top five countries in terms of "Open Budget Index". Achieving this goal will largely contribute to the regular publication of information on the budget in the format of "budget for public", i.e. in a format that ensures openness and accessibility information on the management of state (municipal) finances for citizens.

Placement of fiscal information in the open access, including the format of a "budget for public" in the information and telecommunications network "Internet" has become an important element in ensuring equal and timely access of Russian citizens to information concerning the budget process. In turn, the "more informed civil society can adopt and promote more effective solutions in the fiscal area" (Guidelines for providing fiscal transparency, IMF). But, unfortunately, transparency and openness of the authorities, easy access to information on the status of state and municipal finances, does not automatically increase the citizens' participation in the discussion of budgetary issues. Although this process is becoming more intense, and the numbers of socially active citizens is growing. Increasing of public information about the management of public finances must be accompanied by an increase in budget literacy of Russian citizens; thus budget literacy increasing should be considered as one of the important directions of the educational process development in Russia.

\section{Conclusion}

The experience of recent years shows an increased attention from the federal and regional authorities to the issue of financial literacy of the Russian population and active actions towards its solutions. However, the majority of the population, despite the all levels authorities efforts to improve the situation with fiscal transparency, still has a poor idea of the state budgetary system structure, the formation of the budget, its distribution and use, and of modern fiscal policy.

In order to increase the budget literacy in the Russian Federation the following measures should be undertaken:

- Informing the public about the projects implemented in order to improve budget literacy through the media: newspapers, $\mathrm{TV}$, radio, Internet (currently the majority of the population does not even know about the existence of the "budget for public").

- Development and implementation of budget literacy programs in the system of general and vocational education (it is necessary to start generating interest and increasing budge literacy at school; according to the authors, higher educational establishments should include the course of budget system functioning in any curriculum regardless of the major).

- Organizing workshops for adults.

- Promoting fiscal literacy through the organization of competitions, contests, days of fiscal literacy.

- Arranging annual special sociological research on budget literacy.

The government commission on open government coordination has made "budgets for public" popularization one of its priorities at the federal, regional and local levels with the help of media and contests, preparation of educational programs in the field of fiscal literacy in 2015. Therefore, certain measures in these areas will be taken in 2015. 


\section{References}

1. Behrman, J.R., Mitchell, O.S., Soo, C.K., Bravo, D. How financial literacy affects household wealth accumulation. American Economic Review. 102 (3), 300-304, (2012).

2. Competitive support of initiatives in the field of financial literacy and consumer rights protection. (n.d.). Retrieved June 6, 2015, from http:/goodideasfund.ru/konkurs/

3. Financial literacy of Russian students (by the results of the international program PISA) (n.d.). Retrieved May 6, 2015, from http:/www.minfin.ru/common/upload/library/2015/02/main/PISA_2012.pdf

4. Financial Literacy: who and what to teach? (Results initiative nationwide survey conducted by the National Agency for Financial Studies) (n.d.). Retrieved January 12, 2015, from http://nacfin.ru/finansovaya-gramotnost-kto-i-chemu-dolzhen-uchit/

5. Guidance to ensure transparency in the fiscal area. International Monetary Fund. , Retrieved from https://www.imf.org/external/np/fad/trans/rus/manualr.pdf, (2007).

6. Guthrie, C.P., Nicholls, C.M., The Personal Budget Project: A practical introduction to financial literacy Journal of Accounting Education. 33 (2), 138-163, (2015).

7. Lusardi, A., Financial literacy: Do people know the ABCs of finance? Public Understanding of Science. 24 (3), 260-271, (2015).

8. Lusardi, A., Mitchell, O.S., The economic importance of financial literacy: Theory and evidence. Journal of Economic Literature. 52 (1), 5-44, (2014).

9. Open Government: Results for 2014. (n.d.). Retrieved May 13, 2015, from http://open.gov.ru/infografika/result/

10. Poon, M., Olen, H., Does literacy improve finance? Public Understanding of Science. Public Understanding of Science. 24 (3), 272-284, (2015).

11. Project "Weeks of financial literacy in Russian regions" (n.d.). Retrieved June 15, 2015, from http://fingramota.rcb.ru/

12. Rosfinnadzor report on "On the state of consumer protection in the financial sector in 2013". (n.d.). Retrieved April 23, 2015, from http://www.minfin.ru/common/upload/files/fingram/2y_Publichnyy_doklad_RPN_201 4_FEFLP_QCBS_4_1.pdf

13. Russian Federation President Budget Message on budget policy in 2014-2016. (n.d.). Retrieved March 12, 2015, from http://www.kremlin.ru/acts/18332

14. Russian Financial literacy week is over (2015, 17 March). Retrieved from http://www.minfin.ru/ru/om/fingram/news/\#

15. Sabitova, N.M., Current issues of financial education in Russia. Procedia - Social and Behavioral Sciences. 152, 911 - 915, (2014).

16. Zelentsova A.V. Bliskavka E.A., Demidov D.N. (2012, May 23). Improving financial literacy: international experience and Russian practice. Retrieved from http://www.finansy.ru/st/post_1337760050.html 